\title{
Nosotros vamos a dibujar nuestro propio espacio territorial. Reapropiación del territorio y apropiación de la Cartografía en la Zonal Pewence
}

We will draw our own territorial space. Reappropriation of territory and appropiation of Cartography at the Zonal Pewence

\section{Pablo Daniel Arias}

\section{(2) OpenEdition}

\section{Journals}

Electronic version

URL: http://journals.openedition.org/corpusarchivos/1091

DOI: 10.4000/corpusarchivos.1091

ISSN: 1853-8037

Publisher

Diego Escolar

\section{Electronic reference}

Pablo Daniel Arias, « Nosotros vamos a dibujar nuestro propio espacio territorial. Reapropiación del

territorio y apropiación de la Cartografía en la Zonal Pewence », Corpus [En línea], Vol 2, No 1 | 2012,

Publicado el 30 junio 2012, consultado el 30 abril 2019. URL : http://journals.openedition.org/

corpusarchivos/1091; DOI : 10.4000/corpusarchivos.1091

This text was automatically generated on 30 April 2019.

Licencia Creative Commons: Atribución-NoComercial 2.5 Argentina (CC BY-NC 2.5 AR) 
Nosotros vamos a dibujar nuestro propio espacio territorial. Reapropiación del territorio y apropiación de la Cartografía en la Zonal Pewence

We will draw our own territorial space. Reappropriation of territory and appropiation of Cartography at the Zonal Pewence

Pablo Daniel Arias

\section{EDITOR'S NOTE}

DIRECTOR: Daniel VILLAR

GRADO: LICENCIADO EN HISTORIA

INSTITUCION: Universidad Nacional del Sur

FECHA DE DEFENSA: 27 agosto 2010

CIUDAD: Bahía Blanca 


\section{ABSTRACTS}

Composed of three axes, the thesis is an analysis of the representation of Mapuce territory from a historical and anthropological perspective. Starting from a review of different approaches and anthropological history of cartography, we proceed to study social, economic and political dimensions of the process along with the adoption of mapping practices by members of the Zonal Pewence communities. Finally the case study is confronted with literature concerning similar experiences among other peoples.

The case is considered in the context of the constant pressure by real-estate investors on the territory of the Mapuce communities of the Neuquen Andes and the lack of enforcement of the 26160 Act, which declared the "emergency on possession and ownership of lands traditionally occupied by the original indigenous communities", passed in 2006, and ordered a survey of such lands.

The inquiry is guided by the consideration of different levels of linked contexts. In this matrix of interpretation not only macro processes undergone in the area but also the strategies adopted and actions carried by the communities become intelligible.

Compuesta de tres ejes, la tesina constituye un análisis de la representación del territorio mapuce desde una perspectiva histórica y antropológica. Partiendo de una revisión de diferentes enfoques antropológicos y de la historia de la cartografía, se procede a estudiar las dimensiones sociales, económicas y políticas del proceso acompañado de adopción de prácticas de representación cartográfica por miembros de comunidades de la Zonal Pewence. Finalmente se confronta el caso estudiado con la literatura existente de experiencias similares entre otros pueblos originarios.

El caso es considerado en el contexto de la constante presión de los inversores inmobiliarios sobre el territorio de las comunidades mapuce de los Andes neuquinos y de la inejecución en esa zona de la ley nacional 26160, que, declarando la 'emergencia en materia de posesión y propiedad de las tierras que tradicionalmente ocupan las comunidades indígenas originarias', ordenó, en el año 2006, el relevamiento de esas tierras.

La indagación se guía por la consideración de diferentes niveles de contexto eslabonados. En esa matriz de interpretación cobran inteligibilidad no sólo los procesos macro que se padecen en la zona, sino también las estrategias planteadas y las acciones realizadas por las comunidades.

\section{INDEX}

Keywords: territory, Mapuche, cartography, Pewence Zone, Act 26160

Palabras claves: territorio; mapuche; cartografía; Zonal Pewence; Ley 26160

\section{AUTHOR}

\section{PABLO DANIEL ARIAS}

Universidad Nacional del Sur

Correo electrónico: pablo.d.arias@gmail.com 